\title{
AL ISRA MOSQUE TOILET REDESIGN IN EAST SUDIMARA VILLAGE, CILEDUG DISTRICT, TANGERANG CITY
}

\author{
Anggraeni DYAH*, Harfa ISKANDARIA and Karya SUBAGYA \\ Budi Luhur University, Indonesia \\ *anggraeni.dyah@budiluhur.ac.id
}

\begin{abstract}
A mosque is a place of worship for Muslims. The Ministry of Religion in Indonesia classifies and names the mosques. According to the Ministry of Religion and Dewan Masjid Indonesian (DMI), the classification of mosques: the main Jami mosque at the provincial level is named the Masjid Raya, the main Jami mosque at the district/city level is named the Masjid Agung, the main Jami mosque at the district level is named the Masjid Besar, and mosque at the village level is named Majid Jami. One of the Jami Mosques in Tangerang City is Al Isra Mosque, located on Winong Road, RT.03/RW.05, East Sudimara Village, Ciledug District, Tangerang City, Banten. The Al Isra Mosque was built in 2005 and is currently being developed. In 2018 the Al Isra Mosque was renovated by adding two floors, adding facilities, and changing the facade of the building. One of the facilities that have not been renovated is the toilets (bathroom and ablution). The toilets of the Al Isra Mosque needs to be renovated according to the latest development concept of the Al Isra Mosque. Renovations were carried out on the toilets floor height which was too low, there was only one male toilet, where the male ablution was outside the bathroom, and there were no canopies in the toilets building. Based on these conditions, the Department of Architecture at the Universitas Budi Luhur organized Community Development activities to make the renovation design of the toilets of the Al Isra Mosque. The purpose of the redesign of the mosque of the Al Isra Mosque is that the toilets provides comfort for the Congregation because it matches the architectural standards and the latest concept of the Al Isra Mosque. The method of implementing the activity uses the Architectural Design Process, by input from the Dewan Kemakmuran Masjid and architectural comfort standards. Results redesigning of Al Isra Mosque toilet are shop drawings and RAB by architectural standards, and the latest Al Isra Mosque concept.
\end{abstract}

\section{Keywords: Mosque Toilet, Al Isra Mosque, Redesign, Architectural Standards Community}

\section{BACKGROUND}

Places of worship for Muslims in Indonesia are Mosques, Musala, Langgar, and Surau (Khairuni and Widyanto, 2018). The mosque is a place for the establishment of the five daily prayers continuously, whose land position is waqaf, and can be used for Friday prayers. Mosques are classified according to their service area. The main Jami mosque at the provincial level is called the Grand Mosque, the main Jami mosque at the district/city level is called the Great Mosque, the main Jami mosque at the sub-district level is called the Grand Mosque, and the mosque at the village level is called the Jami Mosque (Kurniawan, 2014).

One of the Jami Mosques in Tangerang City is the Al Isra Mosque which is located on Jalan Winong, RT.03/ RW.05, East Sudimara Village, Ciledug District, Tangerang City, Banten. Al Isra Mosque was built independently by the local community in 2005. The mosque land is waqf land from one of the residents on Jalan Winong. Until now, the $\mathrm{Al}$ Isra Mosque continues to experience development due to the increasing number of congregations and the increasing number of activities accommodated by the mosque. Currently, Al Isra Mosque has a land area of \pm $600 \mathrm{~m}^{2}$ and a building area of $\pm 400 \mathrm{~m}^{2}$ on the $1^{\text {st }}$ floor, and a building area of $\pm 250 \mathrm{~m}^{2}$ on the $2^{\text {nd }}$ floor.

In 2018, the $\mathrm{Al}$ Isra Mosque was renovated independently from one level to two level. The renovation of the number of levels also affects the change in the facade of the building and the improvement of the facilities owned by the mosque. The facade of the building was developed with many openings for natural air circulation thereby reducing the use of artificial air conditioning and changing the colour of the building using pastel colours. Mosque facilities were added by making ablution areas and urinals at the front of the mosque. Only the toilets (bathroom facilities and the ablution area) located at the back of the mosque have not been renovated.

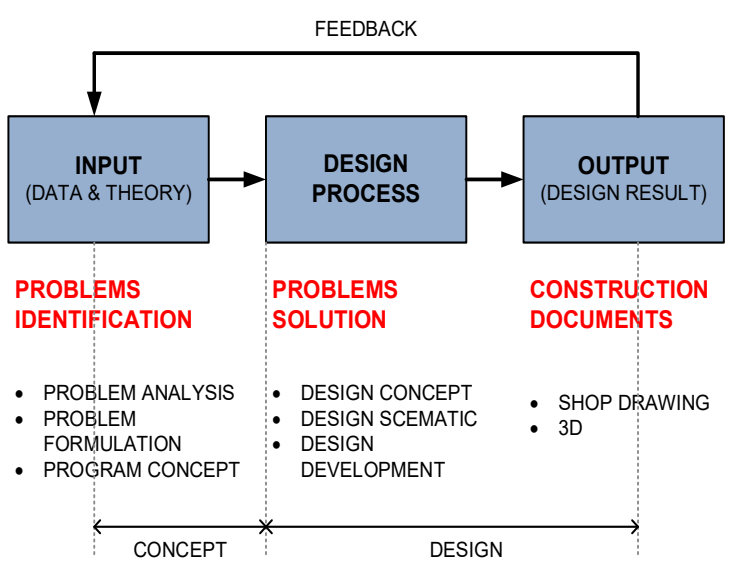

Figure 1. Architectural Design Process

Because the bathroom and ablution at the back of Al Isra Mosque have not undergone renovation, the Architecture Study Program of Budi Luhur University will redesign the renovation of bathroom and ablution at the back of Al Isra Mosque through Community Development activities with the theme "Redesign Toilets of Al Isra Mosque". 


\section{METHODS}

Al Isra Mosque toilets redesign using the Architectural Design Process Method (Waani and Rengkung, 2015).

\section{Input}

Studied problems at the Al Isra Mosque in East Sudimara Village, Ciledug District, Tangerang City. The problem with the Al Isra Mosque is that the toilets located at the back of the mosque have not experienced development when the $\mathrm{Al}$ Isra Mosque development occurred in 2018 (Basit et al., 2009).

\section{Design Process}

Studied the redesign of toilets by the development of the ablution area and urinal facilities located at the front of the Al Isra Mosque. Besides that, it is also studied to redesign bathroom facilities according to architectural comfort standards (Rahmawati and Surakarta, 2016).

\section{Output}

A working drawing of the bathroom facility redesign includes site plan, floor plans, views, cuts, and details as well as exterior and interior 3D drawings (Lantang et al., 2014). The stages of implementing the Redesign of Toilets at Al Isra Mosque in East Sudimara Village, Ciledug District, Tangerang City by the architectural design process.

\section{RESULTS AND DISCUSSION}

\section{Existing}

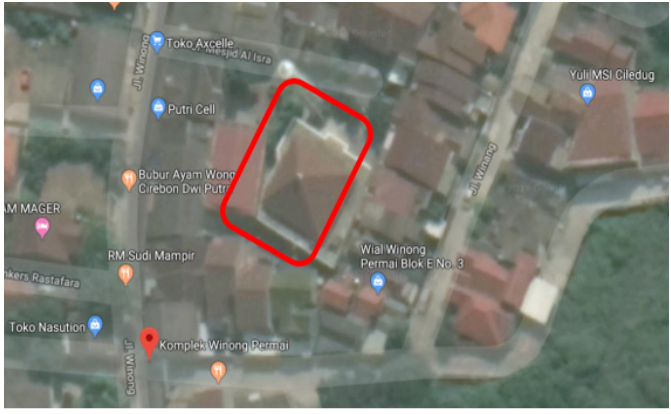

Picture 1. Regional Boundaries Al Isra Mosque

The front facade of the Al Isra Mosque which has undergone renovation in 2018:

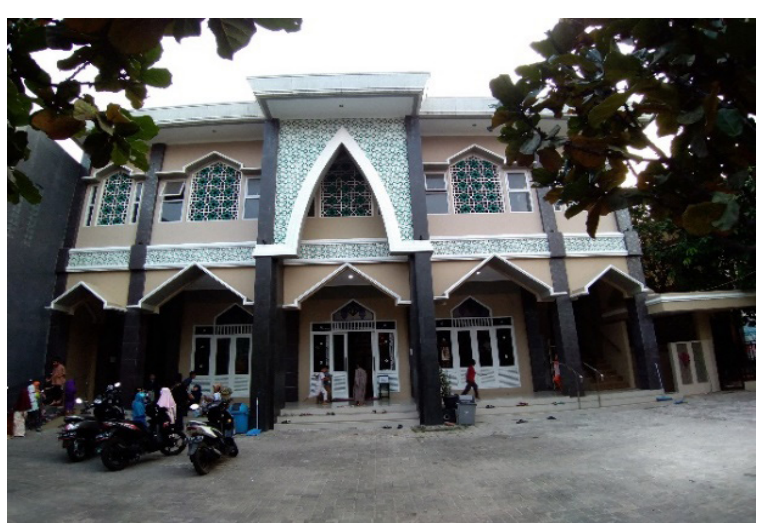

Picture 2. The front facade of the Al Isra Mosque

Al Isra Mosque toilet which has not undergone renovation in 2018:

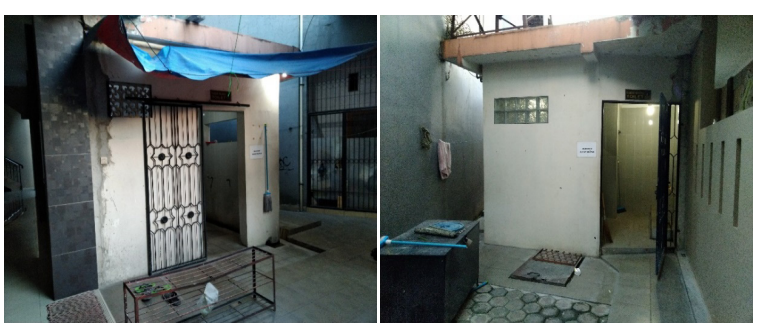

Picture 3. Bathroom of the Al Isra Mosque

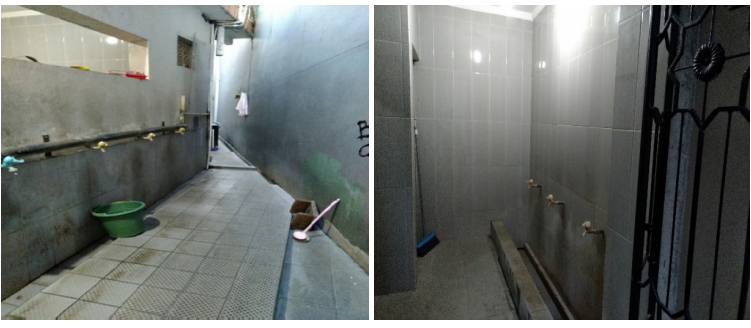

Picture 4. Ablution of the Al Isra Mosque

\section{Design Concept}

First, the redesign concept was carried out by adjusting the toilets of the Al Isra Mosque with the development of the facade of the Al Isra Mosque:

1. The exterior walls are painted in beige color.

2. Columns are painted brown.

3. Opening using a brown karawang.

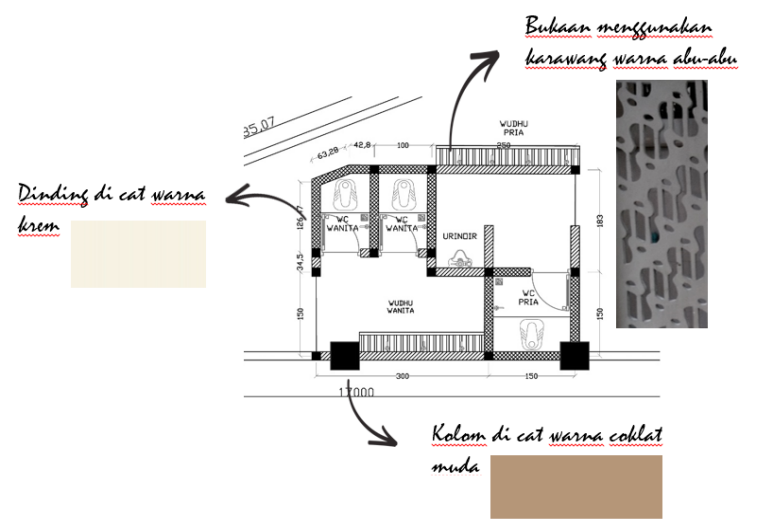

Picture 5. Façade Design Concept

Second, the redesign concept was carried out by adjusting the Al Isra Mosque toilet with architectural comfort standards:

1. Raise the floor height so that it is safe for use by users with disabilities.

2. Adding the number of men's toilets to 2 to make it equal to the number of women's toilets.

3. Provide a variety of squat toilets and sitting toilets to suit the needs of each congregation of the mosque.

4. Move the men's ablution area into the toilet to make it more private and by the women's ablution area located in the toilet.

5. Using waterproof wall material for the men's ablution area so that it is not damp and easy to clean.

6. Adding the width of the toilet roof canopy so that the congregation of the mosque is not exposed to rainwater when going to the toilet.

7. Adding a dividing wall at the entrance to the women's toilet for more privacy. 


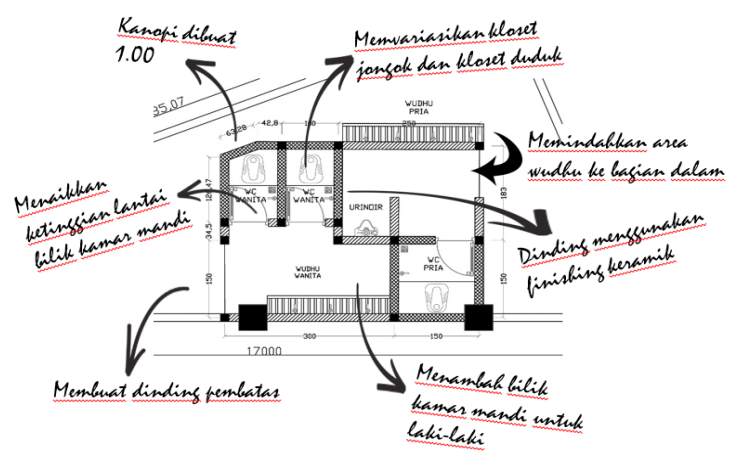

Picture 6. Architectural Standard Design Concept

\section{Design}

The Al Isra Toilets Redesign Concept is based on the current facade of the Al Isra Mosque and is based on architectural comfort standards. Men's ablution area located outside moved into the men's toilet.

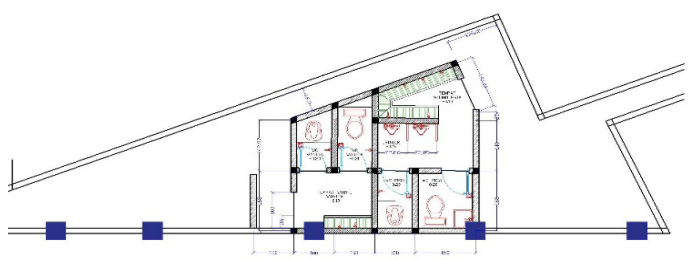

ルLRAS MASUU

\section{Picture 7. Site plan Toilet Al Isra Mosque}

Floor height according to safety standards for disabled users. The entrance to the toilet is given a dividing wall, so it is not visible from the outside. The place for men's ablution is put in the toilet. The men's toilet has been added to two. Each toilet uses a sitting toilet and a squat toilet.

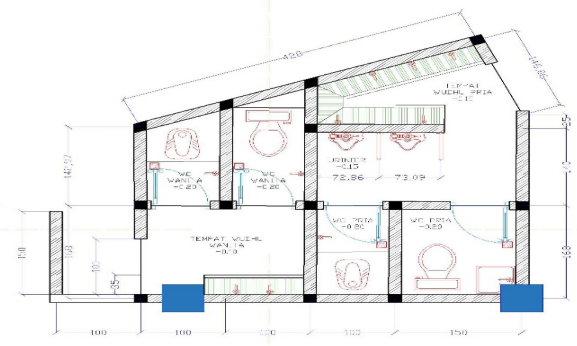

\section{Picture 8. Plan Toilet Al Isra Mosque}

Increasing the width of the toilet canopy roof by 1 meter using aluminum so that it is not expensive.

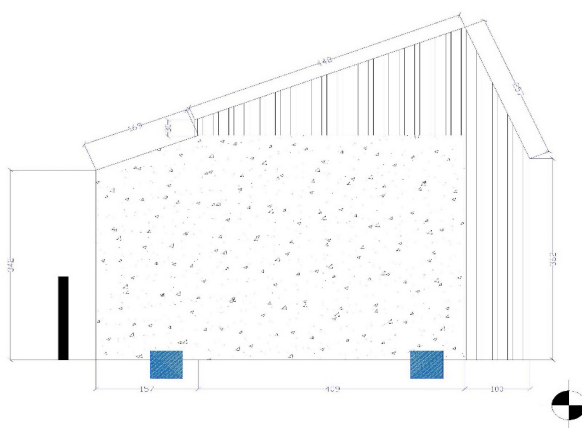

Picture 9. Roof Plan Al Isra Mosque
The windows in the men's and women's ablution areas use a gray karawang. While the window on the toilet uses bouvenlight.

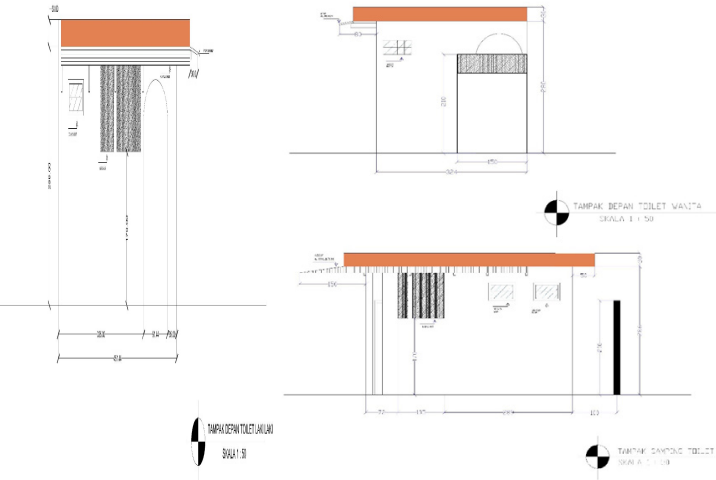

Picture 10. Facade Al Isra Mosque

An additional aluminum canopy roof is placed under the roof deck, making construction easier in the field.
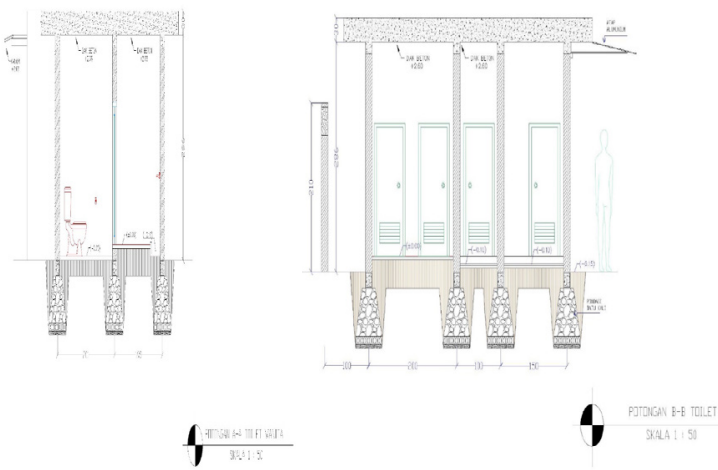

Picture 12. Perspective Al Isra Mosque

In order for the redesign of the toilets of the Al Isra Mosque to be more representative, the working drawings are equipped with 3D images.
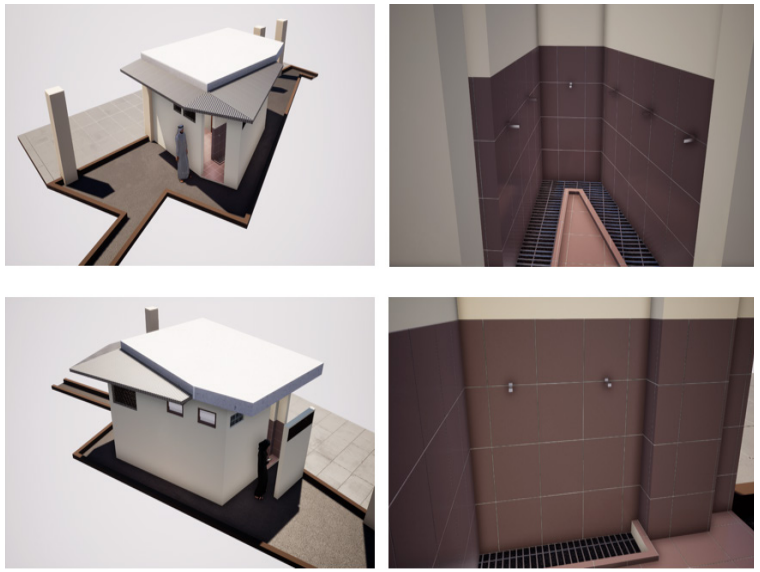

Picture 11. Section Al Isra Mosque

\section{CONCLUSION}

The toilet is one of the mosque facilities. The mosque toilet consists of a bathroom, sink, and ablution area. Mosque toilets must meet the requirements of cleanliness and beauty as well as being pure from najis. The mosque toilet must also be able to accommodate the congregation by the mosque's activities.

For the mosque's toilet to be clean and holy, the design of the mosque's toilet must be by architectural comfort standards. 
Mosque toilets must provide comfort for the disabled. So it takes a special design in the design of space, location of windows, use of materials, and building structures. For the mosque's toilet to be beautiful, an architectural design is needed. The goal is that the mosque's toilet becomes an integral part of the mosque's design.

\section{REFERENCES}

Basit, A., Agama, M., Komunikasi, J., and Purwokerto, S. (2009). Strategi Pengembangan Masjid Bagi Generasi Muda. KOMUNIKA: Jurnal Dakwah dan Komunikasi. 3, 270-286.

Khairuni, N., and Widyanto, A. (2018). Mengatasi Krisis Spiritual Remaja di Banda Aceh Melalui Revitalisasi dan Optimalisasi Fungsi Masjid Sebagai Sarana Pendidikan Islam. DAYAH: Jurnal Islam. Education. 1, 74-84.
Kurniawan, S. (2014). Masjid Dalam Lintasan Sejarah Umat Islam. Jurnal Islam. Studies. 4, 169-184.

Lantang, FN., Sompie, BF., and Malingkas, GY. (2014). Perencanaan Biaya Dengan Menggunakan Perhitungan Biaya Nyata Pada Proyek Perumahan (Studi Kasus Perumahan Green Hill Residence). Jurnal Sipil Statik 2, 73-80.

Rahmawati, N., and Surakarta, UM. (2016). Kenyamanan Ruang Dalam Masjid Dan Pembentukan Generasi Islam. Peran Islam dalam Membangun Peradaban Umat: Bidang Politik, Sosial, Ekonomi, Pendidikan\&Teknologi, 1-11.

Waani, JO., and Rengkung, J. (2015). Teori Dan Metoda Perancangan: Suatu Kajian Pola Pemikiran Josef Prijotomo Terhadap Arsitektur Nusantara. Media Matrasain 12, 17-30. 